\title{
Potensi Bangkitan Penumpang Lintas Jombang-Babat Dalam Menentukan Pemilihan Moda
}

\author{
Theresia M.C.A. ${ }^{1}$, Mutiara Firdausi ${ }^{2}$, Siti Choiriyah $^{3}$ \\ 1,2,3 Teknik Sipil, Fakultas Teknik Sipil dan Perencanaan, Institut Teknologi Adhi Tama Surabaya \\ Email: ${ }^{1}$ theresiamca@itats.ac.id, ${ }^{2}$ mutiara_firdausi89@itats.ac.id,3siti.choiriyah@itats.ac.id
}

\begin{abstract}
In order to serve the movement of passengers an unravel congestion, East Java Government plans to develop its infrastructure and revive the railway lines. Jombang has been selected as the entrance of Gerbangkertosusilo area and is a suitable place for investment. This research attempts to reveal the potential and the movement of passengers that would accur from bus to train, so that the movement probability value and utility value of the bus toward train can be obtained. The survey was conduted in Jombang Kepuhsari Bus Terminal and Babat Market using analytical methods of ststed Preference with variables of Travel Expense (AX1), Travel Time (AX2) and Frequensy of Departeru (AX3). From the results, a model that influence the selevtion of transportation modes is acknowledged, namely $(Y=0,403+0.032(A X 3) .(Y=0,377+0,000003076 \mathrm{AX1}+(0,033 \mathrm{AX} 2)$, and $(Y=0,346+$ 0.00001356 AX1 - 0.031 AX2 + 0.007 AX2). The passengers has potential to switch from bus to train of intersection of the transport system, with a differenc of IDR 6.000,00 of travel expence variable. And variable of Travel Time of 60 minutes and 2 times Frequence Departure
\end{abstract}

Keyword : mode selection, the potential train, trip generation

\begin{abstract}
ABSTRAK
Dalam pergerakan lalu lintas dan mengatasi kemacetan, Kewenangan bagian dari provinsi Jawa Timur akan memperluas moda darat dengan menghidupkan kembali jalur rel kereta api. Jombang dipilih karena sebagai pintu masuk Gerbangkertosusila dan merupakan tempat investasi yang baik. Penelitian ini mencoba mengungkapkan seberapa besar potensi bangkitan dan perpindahan penumpang yang akan terjadi dari moda Bus ke moda jalan rel, sehingga didapatkan nilai probabilitas dan utilitas Bus dengan Kereta Api menurut pelaku pergerakan. Survai dilakukan di Terminal Kepuhsari Jombang dan Pasar Babat dengan menggunakan metode analisis hirarki (Stated Preference) dengan variabel Beban Perjalanan $\left(\Delta \mathrm{X}_{1}\right)$, laju Tempuh Perjalanan $\left(\Delta \mathrm{X}_{2}\right)$ dan Kerapatan Keberangkatan $\left(\Delta \mathrm{X}_{3}\right)$. Dari hasil penelitian didapatkan model yang mempengaruhi pemilihan moda, yakni $(\mathbf{Y}=$ $\left.0,403+0,032 \Delta X_{3}\right),\left(Y=0,377+0,000003076 \Delta X_{1}+\left(0,033 \Delta X_{2}\right)\right.$, dan $\left(Y=0,346+0,00001356 \Delta X_{1}-0,030\right.$ $\Delta \mathbf{X}_{2}+\mathbf{0 , 0 0 7} \Delta \mathbf{X}_{2}$ ). Penumpang berpotensi beralih menggunakan kereta api pada titik perpotongan model, dengan selisih variabel Biaya Perjalanan Rp 6.000,00, variabel Waktu Tempuh Perjalanan selama 60 menit dan Frekuensi Keberangkatan sebanyak 2 kali.
\end{abstract}

Kata kunci: , kereta api, pemilihan moda, potensi bangkitan penumpang

\section{PENDAHULUAN}

Permasalahan transportasi dapat dikatakan kian hari kian kompleks seiring dengan dinamika sosial dan ekonomi masyarakat. Pemerintah Provinsi Jawa Timur berencana mengurai kemacetan di jalan raya dengan menerapkan konsep transportasi massal berbasis rel dengan membangun atau menghidukan kembali jalur rel yang dahulunya ada. Jalur rel tersebut merupakan jalur rel yang telah terintegrasi dengan jaringan jalan rel memutar dalam radius 100-kilometer arah barat Surabaya. Adapun rencana jaringan rel yang memutar tersebut akan segera dikembangkan dengan cara menghidupkan kembali jalur rel dari Jombang ke arah Babat. Jombang dipilih karena sebagai pintu masuk Gerbangkertosusila, dari aspek lokasi peranan Kabupaten Jombang menjadi sangat penting karena sebagai jalur perdagangan dan perekonomian Jawa Timur. 
Berdasarkan alasan tersebut, diperlukan sebuah penelitian untuk mengetahui seberapa besar potensi bangkitan penumpang dan seberapa besar potensi perpindahan penumpang dalam perilaku pemilihan moda (moda choice).

\section{TINJAUAN PUSTAKA}

\section{Konsep Penggunaan Angkutan}

Penggunaan angkutan adalah bagian dari jumlah perjalanan ke suatu cara atau angkutan yang lain. Dalam memilih pilihan moda, perlu diingat dan dipertimbangkan bahwa ada suatu bagian konsumen jasa angkutan yakni paksawan dan pilihwan (Warpani, 2002). Kelompok tersebut antara lain:

- Golongan Paksawan (Captive)

- Golongan Pilihwan (Choice)

Faktor yang dapat memenuhi keinginan dari pemilih angkutan yang akan digunakannya menurut Tamin (2008) dapat dikelompokkan menjadi tiga yang sebagaimana dijelaskan seperti berikut:

- Seorang pengguna jalan.

- Pergerakan dari tujuan

- Penyediaan angkutan umum

Sugiyono dalam bukunya (2012) menyebutkan ada empat jenis skala sikap yakni skala Likert, skala Guttman, Semantic Differensial dan Skala Rating. Dalam penelitian ini lebih mengutamakan untuk menggunakan skala likert dikarenakan untuk mengetahui sikap seperti apa yang nantinya akan diberikan responden mengenai pertanyaan dan pernyataan dalam kuisioner yang diberikan kepada mereka. skalaa pemilihanmemakai penilaian positif hingga negative dengan pemilihan berupa kata yang ada :

a. Pasti Memilih Bus Antar Kota

b. Mungkin Memilih Bus antar Kota

c. Tidak Dapat Memilih Keduanya

d. Mungkin Memilih Angkutan Jalan Rel

e. Pasti Memilih Angkutan Jalan Rel

\section{Pengujian Data}

Menurut Bruton (dalam Fidel Miro, 2004) dalam proses perkiraan jumlah perjalanan dengan menggunakan moda transportasi tertentu banyak berbagai jenis model yang digunakan, akan tetapi model pemilihan diskret merupakan model yang baik jika digunakan untuk dua alternatif moda pilihan. Dasar dari penentuan nilai hasil regresi yang merupakan keinginan dari variable bebas. Dalam mencari nilai hasil regresi menggunakan statistic contoh seperti di bawah ini:

$\mathrm{V}_{\text {konsumen }}=\mathrm{f}\left(\mathrm{x}_{\text {konsumen }}\right)$ atau $\mathrm{V}_{\text {pemakai }}=\mathrm{f}\left(\mathrm{x}_{\text {pemakai }}\right)$

dimana:

$\mathrm{V}_{\text {in }}$ dan $\mathrm{V}_{\mathrm{jn}} \quad=$ nilai kepuasan pengguna angkutan dan pemakai

$\mathrm{x}_{\text {konsumen }}, \mathrm{x}_{\text {pemakai }}=$ tingkat kepentingan dari konsumen

$\mathrm{f} \quad=$ fungsi tingkat kepentingan

Sehingga perumusan regresi merupakan kepuasan konsumen menjadi:

$\mathrm{V}_{\text {in }} / \mathrm{U}=\beta_{1} \mathrm{x}_{\text {in } 1}+\beta_{2} \mathrm{x}_{\text {in } 2}+\ldots \ldots \beta_{\mathrm{k}} \mathrm{x}_{\text {in } \mathrm{k}}$

dimana:

$\mathrm{V}_{\text {in }} / \mathrm{U} \quad=$ kepuasan konsumen memilih angkutan 1(maksimum kepuasan)

$\mathrm{x}_{\text {in1 } 1} \mathrm{~s} / \mathrm{d} \mathrm{x}_{\text {in } \mathrm{k}}=$ tingkat kepentingan dari konsumen sangat besar

$\beta_{1} \mathrm{~s} / \mathrm{d} \beta_{\mathrm{k}} \quad=$ nilai dari beberapa kebebasan 
Dari hasil $\mathrm{V}_{\mathrm{in}} / \mathrm{U}$, harga $\mathrm{V}_{\mathrm{jn}} / \mathrm{U}$ diperoleh, maka harga dimasukkan dalam beberapa bagian pilihan terputus (biner) yang salah satu diantara adalah bagian dari pecahan model. Bentuk pecahan model ini adalah sebagai berikut:

$$
P_{(i)}=\frac{e^{\beta_{x i n}}}{e^{\beta_{x i n}+e^{\beta_{x j n}}}}=\frac{1}{1+e^{-\beta(x i n-x j n)}}
$$

dimana:

$$
\begin{array}{ll}
\mathrm{P}_{(\mathrm{i})} & =\text { kemungkinan } \% \text { angkutan yang dipilih } \\
\beta_{\mathrm{xin}}, \beta_{\mathrm{xjn}} & =\text { harga dari bagian kepuasan memilih angkutan I dan angkutan } \mathrm{j} \\
\mathrm{e} & =\text { pangkat }
\end{array}
$$

Model pecahan model digunakan untuk pilihan dua alternatif angkutan (i dan j).

Pada penelitian ini data yang didapat masih berupa data skala sematik dan harus dirubah menjadi data dengan skala numerik. Proses tranformasi dari batasan sematik ke dalam Batasan angka adalah sebagai berikut:

Contoh: responden A untuk situasi pertama memilih skala pilihan 1, menurut (Berkson - Theil Transformation) skala pilihan 1 bernilai 0,9 pada skala probabilitas, kemudian dari skala probabilitas Ini dirubah ke dalam bentuk skala kuantitatif melalui persamaan:

$$
\operatorname{Ln}\left(\frac{0,9}{1-0.9}\right)=2,1972
$$

Berikut melakukan perhitungan regresi guna mendapatkan bagian dari keseluruhan. Batasan sistem menjadi harga terikat dan kebebasan dari berkurangnya tiap kebebasan. Dengan memakai koefisien lurus akan didapat konstanta $\left(\mathrm{b}_{0}\right)$ dan koefisien $\left(\mathrm{b}_{\mathrm{n}}\right)$ pada masing bagian. Dalam kasus ini moda 1 adalah bus dan moda 2 adalah kereta api, sehingga model utilitas dapat dinyatakan :

$$
\left(\mathrm{U}_{\mathrm{BA}}-\mathrm{U}_{\mathrm{KA}}\right)=\mathrm{b}_{0}+\mathrm{b}_{1}\left(\Delta \mathrm{X}_{1}\right)+\mathrm{b}_{2}\left(\Delta \mathrm{X}_{2}\right) \ldots \ldots . .+\mathrm{b}_{\mathrm{n}}\left(\Delta \mathrm{X}_{\mathrm{n}}\right)
$$
dimana :

$\begin{array}{ll}\mathrm{P}_{\mathrm{BU}} & : \text { pemakai bus } \\ \mathrm{P}_{\mathrm{KA}} & : \text { pemakai jalan rel } \\ \mathrm{U}_{\mathrm{BU}} & : \text { kegunaan bus } \\ \mathrm{U}_{\mathrm{KA}} & : \text { kegunaan jalan rel } \\ \mathrm{b}_{0} & : \text { harga tetap } \\ \mathrm{b}_{1}, \mathrm{~b}_{2}, \ldots \ldots \ldots \ldots \mathrm{b}_{\mathrm{n}} & \text { : harga tidak tetap } \\ \Delta \mathrm{X}_{1}, \Delta \mathrm{X}_{2}, \ldots \ldots \ldots . \Delta \mathrm{X}_{\mathrm{n}} & \text { : penentu bagian harga }\end{array}$

Dari hasil yang didapatkan, didapatkan pemilihan angkutan umum yaitu dengan menggunakan Penyediaan Binomial. Analisis hasil survei dilakukan dengan perhitungan penyediaan. Rumus dasar dari hasil penyediaan untuk menentukan perbandingan nilai tak terhingga negative sampai positif, meski perbandingan terbatas nilai 0 sampai 1. Jika mempunyai pilihan antara menggunakan angkutan jalan rel dan bus, maka probabilitas menggunakan bus adalah $P_{K A}=1-P_{B U}$. Jika $P_{K A}$ dikatakan sebagai kombinasi garis lurus antara faktor bebas dapat ditulis sebagai berikut:

$P_{K A}=a+b_{1}\left(\Delta X_{1}\right)+b_{2}\left(\Delta X_{2}\right)+\ldots . b_{n}\left(\Delta X_{n}\right)$

dimana:

$\mathrm{P}_{\mathrm{KA}} \quad=$ perbandingan pemilihan jalan rel

a $\quad$ pasti

$\mathrm{b}_{1}, \mathrm{~b}_{2}, \ldots \ldots \mathrm{b}_{\mathrm{n}} \quad=$ pe ubah

$\Delta \mathrm{X}_{1}, \Delta \mathrm{X}_{2}, \ldots \ldots . \Delta \mathrm{X}_{\mathrm{n}} \quad=$ variasi pemilihan angkutan

Pemilihan perhitungan aljabar linear antara $P_{K A}$ dengan $1-P_{K A}$, Jika $P_{K A}$ nilai dari nol ke satu, maka $\ln \frac{P_{K A}}{1-P_{K A}}$ niali dari negative ke positif menerus, karena $P_{K A}$ dan $\ln \frac{P_{K A}}{1-P_{K A}}$ tersebut merupakan 
perbandingan lurus dari peubah bebas, maka selanjutnya dapat ditulis sebagai persamaan pemilihan moda:

$\ln \frac{P_{K A}}{1-P_{K A}}=\left(U_{K A}-U_{B U}\right)$

dimana:

$\operatorname{Ln} \frac{P_{K A}}{1-P_{K A}} \quad=\ln$ probabilitas moda Kereta Api

$\mathrm{U}_{\mathrm{KA}} \quad=$ pemakaian angkutan jalan rel

$\mathrm{U}_{\mathrm{BU}} \quad=$ pemakaian angkutan Bus

\section{METODE PENELITIAN}

Metode pengolahan data memakai Stated Preference. Dalam hal ini peneliti berusaha untuk mencari nilai probabilitas dan utilitas terhadap pemilihan moda. Peneliti menggunakan data kualitatif yang kemudian ditransformasikan menjadi data kuantitatif. Form survei berupa lembar kuisioner yang nantinya diisikan dengan metode wawancara dan diberikan langsung kepada responden. Kuisioner ini dibagi menjadi tiga bagian, yakni karakteristik umum orang yang di tanya, bentuk tujuan, dan pemilihan jenis angkutan . Bentuk umum orang yang di tanya terdiri dari: umur, gender, macam kerja, keilmuan tertinggi, dan jumlah pendapatan. Sedangkan karakteristik perjalanan responden terdiri dari: tujuan perjalanan, lama perjalanan, frekuensi keberangkatan, harga perjalanan, kendaraan akses (pra perjalanan), kendaraan purna transport, dan alasan memilih menggunakan alat transportasi tersebut. Serta formulir pemilihan moda yang terdiri dari: variabel perubahan harga tiket, variabel perubahan waktu perjalanan, dan variabel perubahan frekuensi keberangkatan.

Berdasarkan lembar kuisioner yang telah dibuat untuk mendapatkan gambaran mengenai pemilihan moda variabel yang digunakan untuk mengukur adalah Variabel harga Perjalanan $\left(\Delta \mathrm{X}_{1}\right)$, Variabel Perubahan lama Perjalanan $\left(\Delta \mathrm{X}_{2}\right)$, dan Variabel Perubahan macam Keberangkatan $\left(\Delta \mathrm{X}_{3}\right)$. Dari ketiga variabel tersebut, kemudian dikembangkan menjadi Variabel harga Perjalanan - Variabel Perubahan lama Perjalanan $\left(\Delta \mathrm{X}_{4}\right)$, Variabel harga Perjalanan - Variabel Perubahan macam Keberangkatan $\left(\Delta \mathrm{X}_{5}\right)$, Variabel Perubahan lama Perjalanan - Variabel Perubahan macam Keberangkatan $\left(\Delta X_{6}\right)$, dan Variabel Perubahan harga Perjalanan - Variabel Perubahan lama Perjalanan - Variabel Perubahan macam Keberangkatan $\left(\Delta \mathrm{X}_{7}\right)$.

\section{HASIL DAN PEMBAHASAN}

Dengan menggunakan metode statistik deskriptif, berdasarkan hasil rekapitulasi angket surei yang telah berhasil dikumpulkan, karakteristik responden yang didapat adalah sebagai berikut:

a. Usia

Mayoritas responden adalah dengan usia >30 tahun (43\%), usia 20-25 tahun (34\%), usia 25-30 tahun (14\%) dan usia 15-20 tahun (9\%).

b. Jenis Kelamin

Mayoritas responden adalah dengan jenis kelamin laki-laki (53\%) kemudian disusul dengan jenis kelamin perempuan $(47 \%)$.

c. Jenis Pekerjaan

Mayoritas responden adalah Pekerja Swasta (43\%), kemudian Pekerja Lain-Lain (33\%), Pelajar/Mahasiswa (23\%), PNS/ABRI (2\%) dan Pensiunan (2\%).

d. Pensisikan Terakhir

Mayoritas responden adalah dengan lulusan SMA (55\%), SMP (28\%), SD (12\%), Sarjana (3\%), dan Diploma (2\%).

e. Rata - Rata Pendapatan 
Mayoritas responden berpenghasilan $<\mathrm{Rp} 500.000,00$ (35\%), terbanyak kedua Rp 500.000,-Rp 1.000 .000 , (28\%), terbanyak ketiga Rp 1.000.000,-Rp1.500.000, (23\%), terbanyak keempat Rp 1.500.000,-Rp 2.000.000, (10\%), terbanyak kelima Rp 2.000.000, -Rp 2.500.000.000,- (3\%), dan terakhir dengan penghasilan > Rp 2.500.000, (2\%).

f. Maksud Perjalanan

Mayoritas adalah melakukan perdagangan (36\%), melakukan bisnis (21\%), sekolah/kuliah (15\%), melakukan perjalanan untuk mengunjungi saudara (14\%), melakukan perjalanan untuk rekreasi (13\%) dan perjalanan dinas $(2 \%)$.

g. Intensitas Bepergian

Jangka waktu satu bulan responden melakukan perjalanan hampir setiap hari (86\%), sebanyak 7-12 perjalanan satu bulan (7\%), sebanyak 1-6 kali dalam satu bulan (6\%) dan sebanyak 13-24 kali dalam satu bulan $(2 \%)$.

h. Alasan Pemilihan Moda

Alasan utama mereka menggunakan bus adalah kemudahan akses dari dan ke (43\%), pelayanan yang diberikan (25\%), Biaya Perjalanan murah (11\%), waktu tempu yang singkat (10\%), lainnya $(6 \%)$ dan waktu tunggu yang tidak lama $(5 \%)$.

i. Asal dan Tujuan

Rata-rata asal dan tujuan para penumpang adalah Jombang-Babat dan Babat-Jombang yang sesuai dengan target untuk responden kuisioner ini. Meskipun demikian ada beberapa responden yang ternyata bukan berasal dari Jombang, seperti misalnya adalah salah seorang penumpang yang secara kebetulan hendak melakukan perjalanan dari Surabaya menuju Ngimbang, sehingga ia harus berhenti di terminal Kepuhsari untuk berganti moda dengan bus jurusan Jombang-Babat.

j. Waktu Perjalanan

Waktu perjalanan rata-rata yang dibutuhkan untuk waktu akses dari tempat asal menuju terminal yakni 10-15 menit, waktu tunggu yang dibutuhkan selama di terminal yakni 5-15 menit, waktu perjalanan yang dibutuhkan dari terminal hingga ke titik pemberhentian yakni selama 1,5-2 jam dan waktu purna perjalanan rata-rata yakni 20-30 menit.

k. Tarif/Biaya Perjalanan

Biaya rata-rata perjalanan yang dibutuhkan dari tempat asal menuju terminal yakni sebesar Rp $5.000,-\mathrm{Rp} 10.000$,. Biaya rata-rata yang diperlukan dari terminal hingga ke titik pemberhentian sebesar Rp 15.000, - Rp 20.000. Dan biaya rata-rata yang dibutuhkan untuk purna perjalanan sebesar Rp 5.000, - Rp 10.000 .

1. Moda Akses yang Digunakan

Rata-rata para responden menggunakan sepeda motor dan angkot untuk melakukan perjalanan dari tempat asal menuju terminal. Sedangkan dari titik pemberhentian bus menuju tempat tujuan, rata-rata mereka menggunakan angkot.

\section{Pengolahan hasil perhitungan dengan Stated Preference}

Lembar pengisian stated preference disebarkan kepada responden, orang yang mengisi dengan nilai pilihan dalam isian terhadap pemilihan angkutan dengan variabel perubah di dalamnya. Kemudian skala pemilihan tersebut diteruskan menjadi skala perbandingan dimana:

Point 1 - JelasMemilih Bus

Point 2 - Bisa Memilih Bus

$\mathrm{p}=0,9$

Point 3 - Tidak Memilih Keduanya

$\mathrm{p}=0,7$

Point 4 - Bisa Memilih Kereta Api

$\mathrm{p}=0,5$

Point 5 - JelasMemelih Kereta Api

$\mathrm{p}=0,3$

$\mathrm{p}=0,1$ 
Tabel 1 Nilai Utilitas Skala Pemilihan

\begin{tabular}{|c|c|c|c|}
\hline $\begin{array}{c}\text { Skala } \\
\text { Pemilihan }\end{array}$ & Keterangan & $\begin{array}{c}\text { Skala } \\
\text { Probabilitas }\end{array}$ & $\begin{array}{c}\text { Utilitas } \\
\text { Ln }\left(\frac{\boldsymbol{P}}{\mathbf{1}-\boldsymbol{P}}\right)\end{array}$ \\
\hline 1 & Pasti Memilih Bus & 0,0 & 2,197 \\
\hline 2 & Mungkin Memilih Bus & 0,7 & 0,9847 \\
\hline 3 & Tidak Memilih Keduanya & 0,5 & 0 \\
\hline 4 & Mungkin Memilih KA & 0,3 & $-0,847$ \\
\hline 5 & Pasti Memilih KA & 0,1 & $-2,197$ \\
\hline
\end{tabular}

\section{Persepsi Pemilihan Moda}

1. Perubahan Biaya Perjalanan $\left(\Delta X_{1}\right)$

Persamaan model : $\mathrm{Y}=0,642-\left(0,00002312 \Delta \mathrm{X}_{1}\right)$

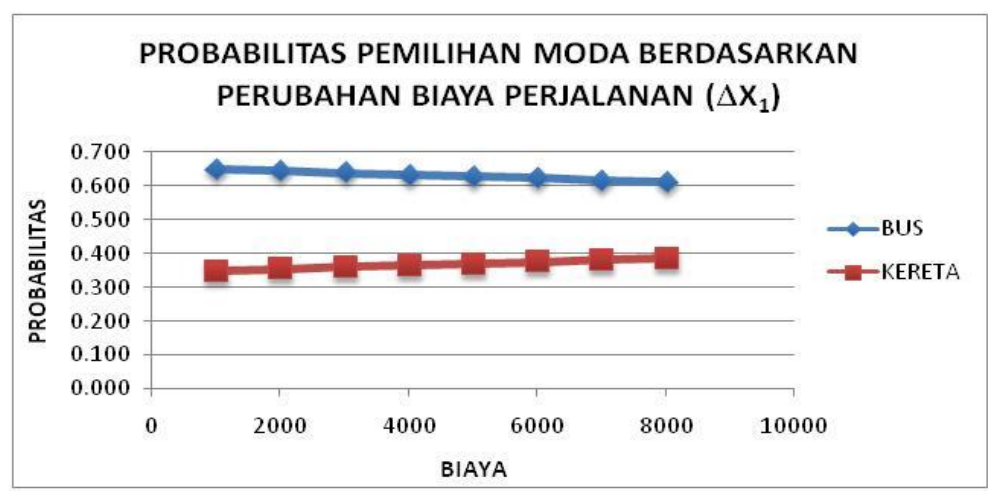

2. Perubahan Waktu Tempuh Perjalanan $\left(\Delta X_{2}\right)$

Persamaan model : $\mathrm{Y}=0,485+\left(0,000 \Delta \mathrm{X}_{2}\right)$

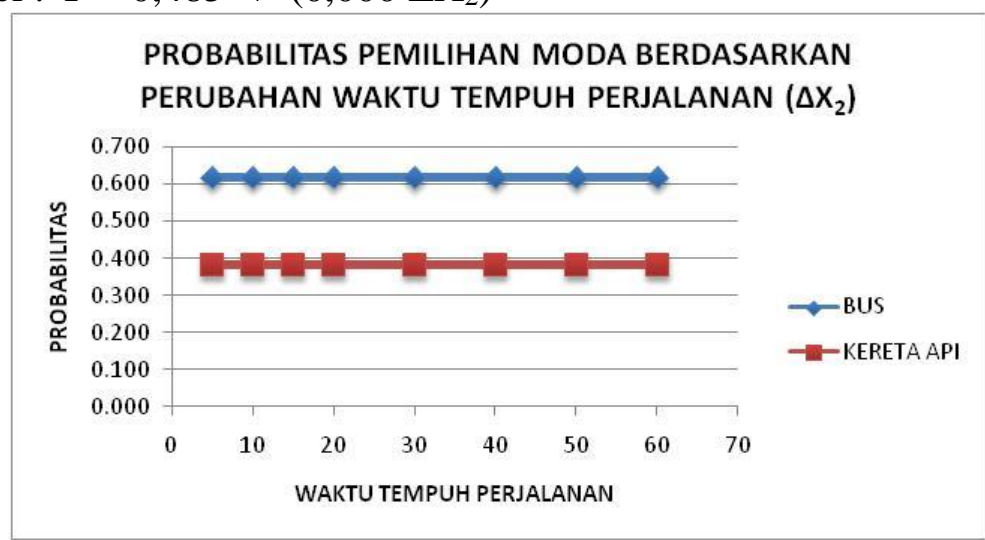


3. Perubahan Frekuensi Keberangkatan $\left(\Delta X_{3}\right)$

Persamaan model : $\mathrm{Y}=0,403+\left(0,032 \Delta \mathrm{X}_{3}\right)$

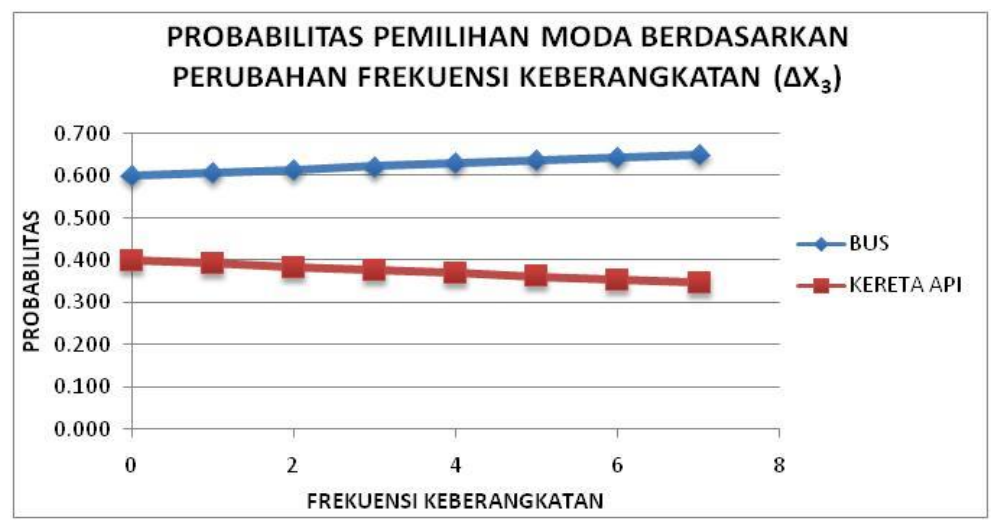

4. Perubahan Biaya Perjalanan dan Waktu Tempuh Perjalanan $\left(\Delta X_{1}\right.$ dan $\left.\Delta X_{2}\right)$ Persamaan model : $\mathrm{Y}=0,626-\left(0,00002993 \Delta \mathrm{X}_{1}\right)+\left(0,000 \Delta \mathrm{X}_{2}\right)$

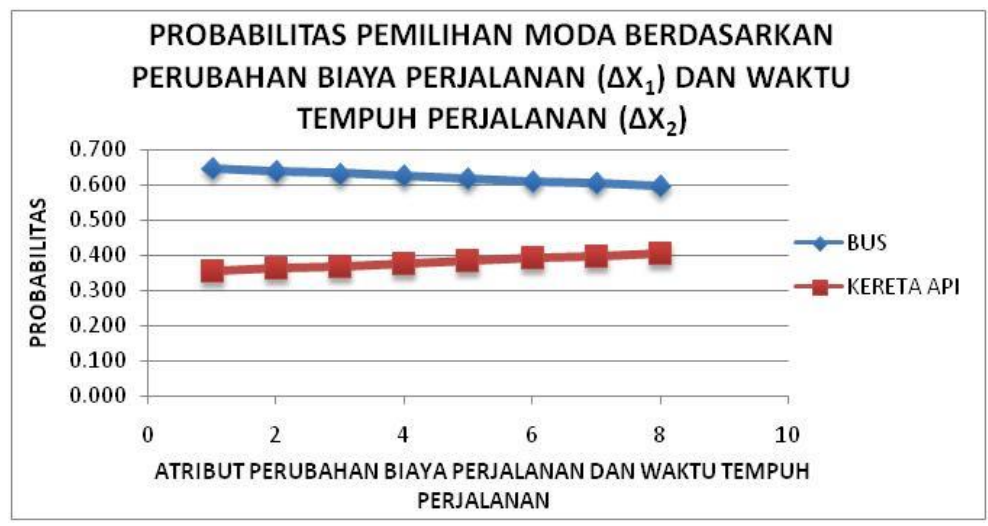

5. Perubahan Biaya Perjalanan dan Frekuensi Keberangkatan $\left(\Delta X_{1}\right.$ dan $\left.\Delta X_{3}\right)$ Persamaan model : $\mathrm{Y}=0,377+\left(0,000003076 \Delta \mathrm{X}_{1}\right)+\left(0,033 \Delta \mathrm{X}_{2}\right)$

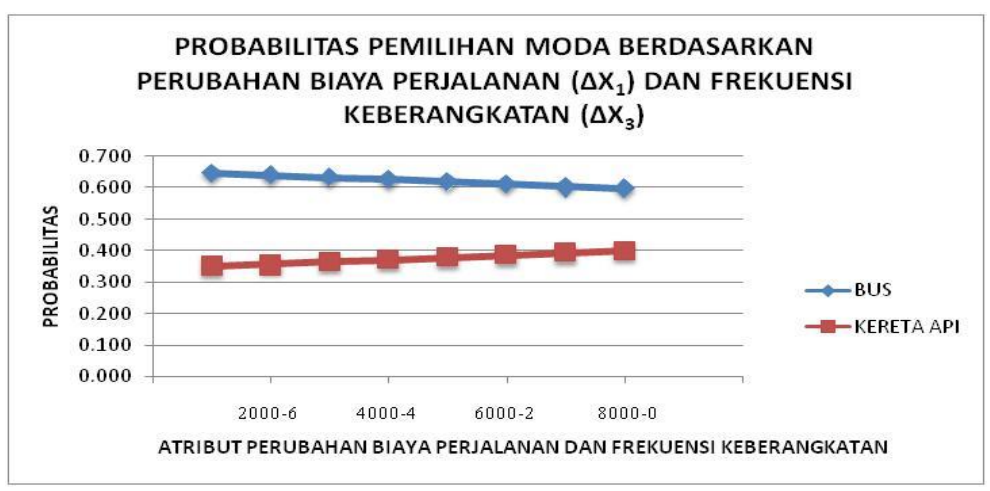


6. Perubahan Waktu Tempu Perjalanan dan Frekuensi Keberangkatan $\left(\Delta X_{2}\right.$ dan $\left.\Delta X_{3}\right)$ Persamaan model : $\mathrm{Y}=0,387+\left(0,042 \Delta \mathrm{X}_{1}\right)-\left(0,002 \Delta \mathrm{X}_{2}\right)$

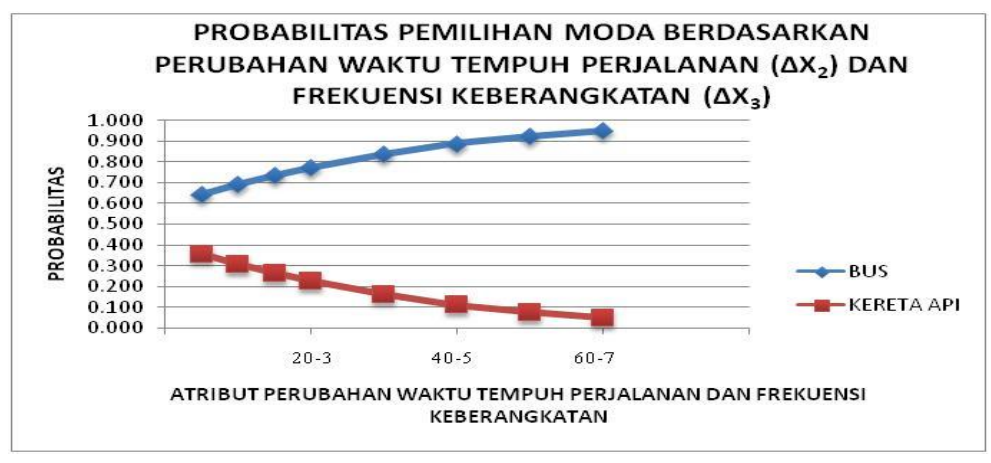

7. Perubahan Biaya Perjalanan, Waktu Tempuh Perjalanan dan Frekuensi Keberangkatan $\left(\Delta \mathrm{X}_{1}, \Delta \mathrm{X}_{2}\right.$ dan $\left.\Delta \mathrm{X}_{3}\right)$

Persamaan model : $\mathrm{Y}=0,346+\left(0,00001356 \Delta \mathrm{X}_{1}\right)-\left(0,030 \Delta \mathrm{X}_{2}\right)+\left(0,007 \Delta \mathrm{X}_{3}\right)$

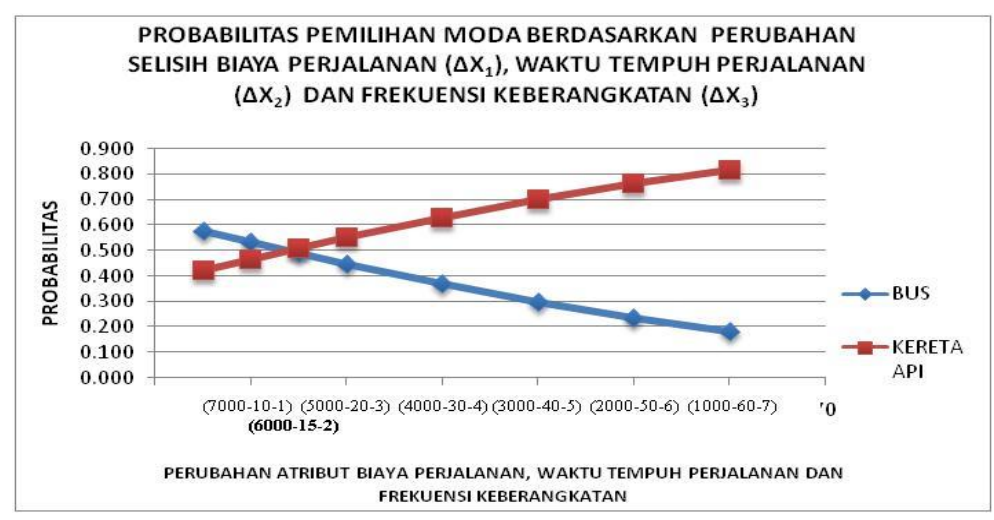

\section{KESIMPULAN DAN SARAN}

- Hasil akhir dari penelitian:

1 Sebanyak $43 \%$ responden merupakan pekerja. Rata-rata (35\%) pendapatan para responden berada di kisaran $<\operatorname{Rp~500.000,00.~Maksud~perjalanan~rata-rata~para~responden~}(36 \%)$ bertujuan untuk berdagang Waktu perjalanan rata-rata yang dibutuhkan untuk waktu akses dari tempat asal menuju terminal yakni 10-15 menit, waktu tunggu yang dibutuhkan selama di terminal yakni 5-15 menit, waktu perjalanan yang dibutuhkan dari terminal hingga ke titik pemberhentian yakni selama 1,5-2 jam dan waktu purna perjalanan rata-rata yakni 20-30 menit

2 Biaya rata-rata perjalanan yang dibutuhkan dari tempat asal menuju terminal yakni sebesar $\mathrm{Rp} 5.000$, - Rp 10.000, Biaya rata-rata yang diperlukan dari terminal hingga ke titik pemberhentian sebesar $\mathrm{Rp} 15.000,-\mathrm{Rp} 20.000$. Dan biaya rata-rata yang dibutuhkan untuk purna perjalanan sebesar Rp 5.000, - Rp 10.000,

3 Hampir sebagian besar responden (43\%) memilih menggunakan bus dikarenakan kemudahan akses dan ke tujuan masing-masing. Berdasarkan permodelan dari variabel harga Perjalanan $\left(\Delta X_{1}\right)$, lama Perjalanan $\left(\Delta X_{2}\right)$ dan macam Keberangkatan $\left(\Delta X_{3}\right)$ didapatkan 7 persamaan model pemilihan moda akan tetapi tidak ada yang memiliki nilai sig. sehingga apabila dijadikan sebuah acuan permodelan kurang signifikan 
4 Hanya terdapat 3 persamaan yang dapat mewakili dari permodelan pemilihan moda transportasi, yakni persamaan 3 yang merupakan pemilihan moda berdasarkan variabel Frekuensi Keberangkatan $\left(\mathbf{U}_{\mathbf{B U}}-\mathbf{U}_{\mathbf{K A}}=\mathbf{0 , 4 0 3}+\mathbf{0 , 0 3 2} \Delta \mathbf{X}_{\mathbf{3}}\right)$, persamaan 5 yang merupakan pemilihan moda berdasarkan Biaya Perjalanan dengan Frekuensi Keberangkatan $\left(\mathbf{U}_{\mathbf{B U}}-\mathbf{U}_{\mathbf{K A}}\right.$ $=\mathbf{0 , 3 7 7}+\mathbf{0 , 0 0 0 0 0 3 0 7 6} \Delta \mathbf{X}_{\mathbf{1}}+\left(\mathbf{0 , 0 3 3} \Delta \mathbf{X}_{2}\right)$, dan persamaan 7 yang merupakan pemilihan moda bedasarkan Biaya Perjalanan, Waktu Tempuh Perjalanan dan Frekuensi Keberangkatan $\left(\mathbf{U}_{\mathbf{B U}}-\mathbf{U}_{\mathbf{K A}}=\mathbf{0 , 3 4 6}+\mathbf{0 , 0 0 0 0 1 3 5 6} \Delta \mathbf{X}_{\mathbf{1}}-\mathbf{0 , 0 3 0} \Delta \mathbf{X}_{\mathbf{2}}+\mathbf{0 , 0 0 7} \Delta \mathbf{X}_{\mathbf{2}}\right)$.

5 Besar potensi bangkitan penumpang yang akan terjadi diperkirakan dari variabel-variabel persamaan di atas. Dari variabel hargaPerjalanan $\left(\Delta \mathrm{X}_{1}\right)$ sebanyak $32 \%$ responden memilih pasti menggunakan kereta api. Dari variabel Lama Perjalanan $\left(\Delta \mathrm{X}_{2}\right)$ sebanyak $38 \%$ responden memilih pasti menggunakan kereta api. dari variabel macam Keberangkatan $\left(\Delta \mathrm{X}_{3}\right)$ sebanyak $35 \%$ responden pasti menggunakan kereta api. Dari variabel harga Perjalanan $\left(\Delta \mathrm{X}_{1}\right)$ dan lama Perjalanan $\left(\Delta \mathrm{X}_{2}\right)$ sebanyak $34 \%$ responden memilih pasti menggunakan kereta api. Dari variabel harga Perjalanan $\left(\Delta X_{1}\right)$ dan macamKeberangkatan sebanyak $\left(\Delta X_{1}\right) 37 \%$ responden memilih pasti menggunakan kereta api. Dari variabel Waktu Tempuh Perjalanan $\left(\Delta \mathrm{X}_{2}\right)$ dan macam Keberangkatan $\left(\Delta \mathrm{X}_{3}\right)$ sebanyak $36 \%$ responden memilih pasti menggunakan kereta api. dan dari variabel harga Perjalanan $\left(\Delta \mathrm{X}_{1}\right)$, lama Perjalanan $\left(\Delta \mathrm{X}_{2}\right)$ dan macamKeberangkatan $\left(\Delta \mathrm{X}_{3}\right)$ sebanyak $34 \%$ responden memilih pasti menggunakan kereta api.

6 Besar perpindahan pengguna dari bus menuju angkutan jalan rel dapat dilihat dari persamaan 7. Dari hasil perhitungan probabilitas didapatkan titik keseimbangan dari ketiga variabel tersebut yakni terdapat perpotongan garis linier antara bus dengan kereta api pada titik $\Delta \mathrm{X}_{1}$ $=6000, \Delta X_{2}=15$ dan $\Delta X_{3}=2$. Hal ini dapat diartikan jika kedua moda tersebut jika memiliki selisih Biaya Perjalanan Rp 6.000,00 dengan selisih Waktu Tempuh Perjalanan selama 60 menit dan dengan selisih Frekuensi Keberangkatan sebanyak 2 kali, maka orang yang tadinya memilih bus akan berpeluang memilih menggunakan kereta api.

\section{REFERENSI}

Ghozali, Imam.2013. Aplikasi Analisis Multivariate dengan Program IBM SPSS 21 Update PLS Regresi. Semarang: Badan Penerbit Universitas Diponegoro.

Hartono. 2010. SPSS 16.0 Analisis Data Statistika dan Penelitian. Yogyakarta: Pustaka Pelajar.

Masry S, Maringan. Ekonomi Transportasi. Jakarta: Ghalia Indonesia.

Miro, Fidel. 2004. Perencanaan Transportasi untuk Mahasiswa, Perencana, dan Praktisi. Jakarta: PT. Gelora Aksara Pratama.

Nasution. 2008. Manajemen Transportasi (Edisi Ke 3). Bogor: Ghalia Indonesia

Sudjana. 2005. Metoda Statistika. Bandung: PT. Tarsito Bandung.

Sugiyono. 2012. Metode Penelitian Pendidikan (Pendekatan Kuantitatif, Kualitatif, dan R\&D). Bandung: Alfabeta.

Sugiyono. 2012. Statistika untuk Penelitian. Bandung: Alfabeta.

Tamin, Ofyar Z. 2008. Perencanaan, Permodelan dan Rekayasa Transportasi : Teori, Contoh Soal, dan Aplikasi. Bandung: ITB.

Warpani, Suwardjoko. 2002. Pengelolaan Lalu Lintas dan Angkutan Jalan. Bandung: ITB. 